\title{
DRYING OF EGGPLANT SLICES USING MICROWAVE-OVEN
}

\author{
Keshek' M. H. ${ }^{(1)}$; Omar, M. N. ${ }^{(1)}$ and Amer Eissa, A. H. ${ }^{(2)}$
}

\begin{abstract}
Eggplant (Solanum melongena L.) is considered one of the most important crops in summer season, and it is grown in most cultivated area in Egypt. Eggplant has a very limited shelf life for freshness and physiological changes occur after harvest. Nowadays, microwave drying offers an alternative way to drying agricultural products. Microwave drying is not only faster but also requiring less energy consumption than conventional drying. The main objective of this research was to evaluate using the microwave oven in Eggplant drying, to determine the optimum drying time of higher drying efficiency and lower energy consumption. The eggplants slices, having a thickness of about 5, 10, 15, and $20 \mathrm{~mm}$, with diameter $50 \pm 2 \mathrm{~mm}$ was dried using microwave oven (KOR-9G2B) using three different levels were 450, 630, and $810 \mathrm{Watt}$ (50\%, 70\%, and 90\% of 900 Watt). The results show that, the initial moisture content of the eggplant slices was around $93 \%$ wet basis (13.28 g water/g dry matter). The results indicated that, the moisture transfer within the sample was more rapidly during higher microwave power heating (810 watt) and lower thickness (5 $\mathrm{mm}$ ) of the eggplant slices. In addition, the results show that, the drying efficiency increases by increasing slices thickness at power levels 450, 630 and 810 Watt. The higher drying efficiency was $83.13 \%$ occurred when drying the eggplant slices $20 \mathrm{~mm}$ thickness in microwave oven at power 630 Watt. the higher total energy consumption per dry kilogram was 1.275 ( $\mathrm{kWh} /$ dry $\mathrm{kg}$ ) occurred at used microwave 810 Watt for drying eggplant slices $5 \mathrm{~mm}$ thickness, and the lower total energy consumption per dry kilogram was 0.55 ( $\mathrm{kWh} /$ dry $\mathrm{kg}$ ) occurred at used microwave 810 Watt for drying eggplant slices $20 \mathrm{~mm}$ thickness.
\end{abstract}

Keywords: Microwave drying, Eggplant, Drying rate, Drying efficiency, Energy consumption

\footnotetext{
(1) Lecturer, Agricultural Engineering Department, Menoufia University

(2) Professor of Food Processing Engineering, Agricultural Engineering Department, Menoufia University
} 


\section{1-INTRODUCTION}

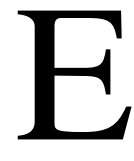

ggplant (Solanum melongena L.) is cultivated in North America, Asia and the Mediterranean area (Puig et al. 2012). Generally, Eggplant is enlisted as classical commodity for both local consumption and exportation. Eggplant is grown in most cultivated area in Egypt, and it is considered one of the most important crops in summer season (Rakha, 2014). According to (FAO, 2015) production of eggplant is highly concentrated with $90 \%$ output coming from five countries (China, India, Egypt, Turkey, and Indonesia). Egypt is the third producer $2.94 \%$ of total world production with amounted to over 1.229.790 million tones.

Eggplant has a very limited shelf life for freshness and physiological and morphological changes occur after harvest. Its limited shelf life is one of the important restrictions in the trade of eggplant as a fresh product. Dehydration constitutes an alternative method to provide more stable eggplant products, which may be shipped to foreign markets or used locally during the whole year (Puig et al., 2012). It is common to dry eggplants to extend shelf lives. Dried eggplant can be used as an ingredient in different kinds of meals, instant soups, and sauces, (Ertekin and Yaldiz, 2004). Drying is a removal of moisture from the food materials to prevent the growth and reproduction of spoilage microorganisms and to slow down the action of enzymes and minimize many of the moisture mediated deteriorative reactions (Wu et al., 2007). By drying, moisture content is reduced to a level, which allows safe storage over an extended period (Doymaz, 2011).

Microwave drying has the advantages of selective heating, energy efficiency, speed and requirement of less floor space. Microwave Drying is not only faster but also requiring less energy consumption than conventional drying (Schiffmann, 2001). Microwave drying has been recently used for drying of fruits and vegetables such as apple (Chong et al., 2014), carrot (Arikan et al., 2012), and mango ginger (Murthy and Manohar, 2012). Microwave energy offers several benefits compared to conventional heating methods, including speed of operation, energy savings, precise process control and quicker start-up and shut down times (Botha et al., 2012). A low microwave power may lead to a low drying temperature and a slow drying rate; while a high microwave power may lead to an undesirable high temperature, may enhance the uneven 
distribution of the microwave energy, and may damage the quality of the final product. Therefore, microwave-drying method has been applied successfully to some food materials (Arslan and Ozcan 2011). (Sousa et al., 2004) observed that increasing microwave power during the final drying of banana slices increases the drying rate and consequently decreases drying time. However, higher microwave power also causes a rapid rise in product temperature (temperature runaway) and consequently charring of the dried product. Thus, it is necessary to control the microwave power during the final drying phase in order to avoid temperature runaway and quality deterioration of the product.

(Aydogdu, 2014) studied the effects of hot air drying and microwaveinfrared combination drying on porous structure of eggplants. Hot air drying was performed in a tray dryer at $50^{\circ} \mathrm{C}$ with an air velocity of $1.5 \mathrm{~m}$ s-1. In microwave-infrared combination oven, different microwave powers (30\%, $40 \%$ and $50 \%)$ were combined with different infrared powers $(10 \%$, $20 \%)$. During drying process, initial moisture content decreased from 14 $\mathrm{kg}$ water kg-1 dry solid to approximately $0.13 \mathrm{~kg}$ water $\mathrm{kg}-1$ dry solid for eggplants. Microwave-infrared combination drying provided more porous structure than hot air-dried ones due to higher internal pressure. As infrared and microwave power increased, threshold diameter increased and eggplants with more porous structure were obtained. Texture, appearance, color, flavor, taste and nutritional value are affected from drying process conditions. Elephant foot yam plant was dried under different microwave power ranging from $180 \mathrm{~W}$ to $900 \mathrm{~W}$ and sample thickness $(5-15 \mathrm{~mm})$ to study their effect on microwave drying kinetics. Drying time, drying rate, kinetic rate constant, effective moisture diffusivity and rehydration ratio are various factors studied. Increase in microwave power and decrease in sample thickness increased drying rate and decrease the drying time (Harish et al, 2014).

In general, drying involves two simultaneous processes which are heat transfer for evaporation of water and mass transfer of water vapor (Berk, 2009). Since the products to be dried have different shapes, moisture contents and temperature sensitivity, the drying conditions such as drying time, drying temperature, amount of heat to be supplied, and amount of water vapor to be removed can be changed (Margaris and Ghiaus, 2008). Heat and mass transport phenomena affect the quality of dehydrated foods. 
Texture, appearance, color, flavor, taste and nutritional value are affected from drying process conditions. Therefore, deciding suitable drying system is very important for food products. While drying conditions has been selected, type of feed, amount of moisture, drying kinetics, heat sensitivity, physical structure of the material to be dried and quality requirements of a dried food should be regarded (Jangam, 2011).

The main objective of this research was to evaluate using the microwave oven in eggplant drying. Secondary, to determine the optimum drying time of higher drying efficiency and lower energy consumption when using microwave oven.

\section{MATERIALS AND METHODS:}

Eggplants (Solanum melongena L.) which were used in this study were collected from the local market, samples were washed by water, peeled, and cut into slices, having a thickness of about 5, 10, 15, and $20 \mathrm{~mm}$ using a kitchen slicer, with diameters of the eggplant's samples were $50 \pm 2 \mathrm{~mm}$. The initial moisture content of eggplant was found to be $93 \%$ dry solid by using a moisture analyzer. The eggplants samples drying was done using microwave oven (KOR-9G2B) as shown Fig. (1) using three different levels of the maximum oven output of $900 \mathrm{~W}$ and $2450 \mathrm{MHz}$, which were 450,630 , and 810 Watt (50\%, 70\%, and 90\% of 900 Watt).

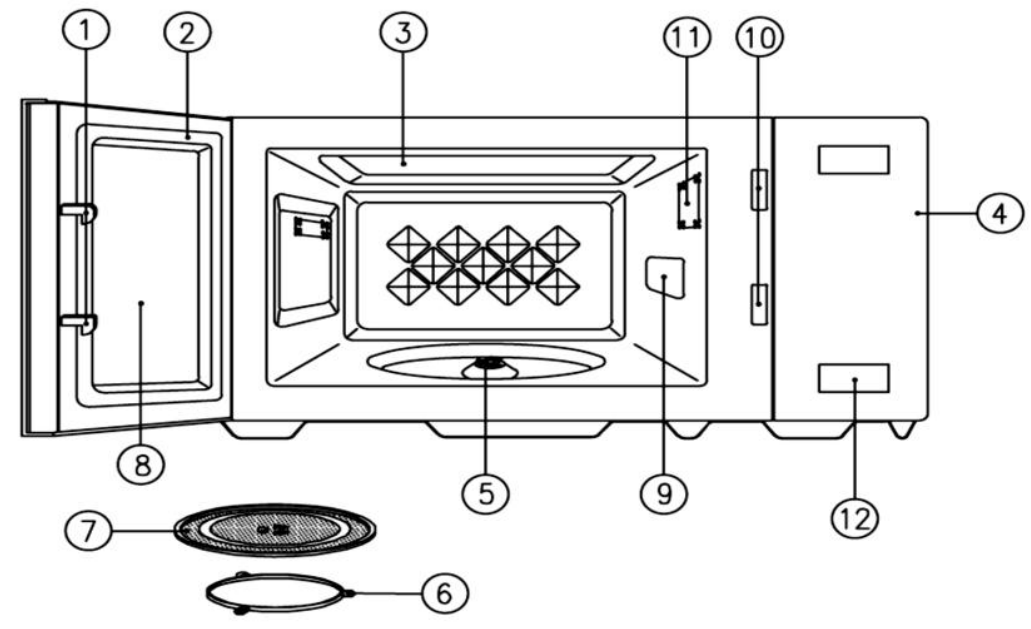
1. Door latch.
2. Door seal.
3. Oven cavity.
4. Control panel.
5. Coupler.
6. Roller guide.
7. Glass cooking tray
8. Viewing screen.
9. Waveguide cover.
10. Safety interlock system.
11. Oven lamp.
12. Door open button.

Fig (1) Microwave oven (KOR-9G2B). 


\subsection{Samples Drying procedures:}

Eggplants were washed by water and peeled. The eggplants were cut into slices, having a thickness of about 5, 10, 15, and $20 \mathrm{~mm}$ using a kitchen slicer. Cut the eggplant samples into slices with diameter of $50 \pm 2 \mathrm{~mm}$ using especially cylinder with a sharp edge. Weight eggplant slices before placing it in the microwave oven to dry. Dry the eggplant slices in microwave oven when adjusted for working with different levels of microwave powers $(810,630$, and $450 \mathrm{~W}$ of microwave power). In each case, 16 samples of eggplant (with covering about $90 \%$ of the whole diameter of microwave rotary tray) were arranged in the microwave oven in ordered to dry until a required final moisture content as shown in Figure (2). To calculate the drying rate and drying efficiency, the weight of each sample was recorded every three minutes until the burning point of the samples. Secondly, the weight of each sample was recorded every minute until the burning point of the samples. Thirdly, the weight of each sample was recorded every 10 seconds until the burning point of the samples. The experimental treatments were replicated three times.

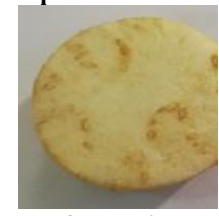

Befor drying

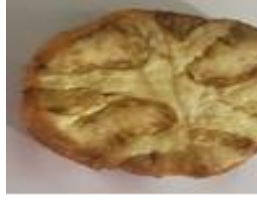

At constant drying rate period

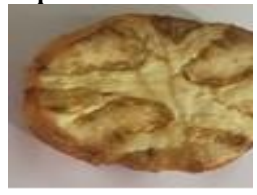

At falling drying period

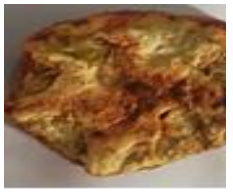

After drying and before burning

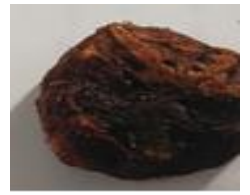

After Burning

Fig. (2) Arrangement of the eggplant samples during drying stages.

\subsection{Initial moisture content determination:}

It was determined according to the method approved by the (AOAC, 1980). The samples of eggplants slices were placed into the oven at $70{ }^{\circ} \mathrm{C}$ and left 24 hours. After this period, the samples were collected and placed into the desiccator to avoid gaining moisture from the atmosphere and left after cooling down, and then the samples were weighed again.

$$
\mathrm{M}_{\mathrm{wb}}==\frac{w_{o}-w_{d}}{w_{o}} * 100, \%
$$

While the moisture content on the dry basis $(\mathrm{Mdb})$ is the weight of moisture present in the product per unit weight of dry matter in the product and represented as,

$$
\mathrm{M}_{\mathrm{db}}=\frac{w_{o}-w_{d}}{w_{d}} * 100 \%
$$


For the duration of drying experiments, where weight losses are recorded, the instantaneous moisture contents at any given time $\left[\mathrm{M}_{\mathrm{twb}}\right.$ and $\left.\mathrm{M}_{\mathrm{tdb}}\right]$ can be computed according to the following equations Mohamed et al., (2010):

$$
\begin{gathered}
M_{t w b}=1-\left(\frac{\left(1-M_{o w b}\right) * W_{o}}{W_{t}}\right) * 100 \% \\
M_{t d b}=\left(\left(\frac{\left.1+M_{o d b}\right) * W_{t}}{W_{o}}\right)-1\right) * 100 \%
\end{gathered}
$$

Where:-

$\mathrm{Wd}=$ weight of dry matter in product, $\mathrm{kg}$

Wo $=$ initial weight of fresh product, $\mathrm{kg}$

$\mathrm{Wt}=$ weight of product at time ( $\mathrm{t}), \mathrm{kg}$.

\subsection{Energy Efficiency:}

The microwave drying efficiency was calculated as the ratio of heat energy utilized for evaporating water from the sample to the heat supplied by the dryer (Soysal et al., 2006).

$$
\eta=\frac{\mathbf{m}_{\mathbf{w}} \times \lambda_{\mathrm{w}}}{\mathbf{P} \times \mathbf{t}} \times \mathbf{1 0 0} \%
$$

where $\eta$ is the microwave-convective drying efficiency (\%); $\mathrm{P}$ is the microwave power $(\mathrm{W}) ; \mathrm{m}_{\mathrm{w}}$ is the mass of evaporated water $(\mathrm{kg})$, and $\lambda_{\mathrm{W}}$ is the latent heat of vaporization of water $(2257 \mathrm{~kJ} / \mathrm{kg})$.

The drying rate of eggplant slices was calculated using equation (2) Akpinar, and Bicer, (2005):-

$$
\mathrm{DR}=\frac{M_{t+d t}-M_{t}}{d t}
$$

where $\mathrm{M}_{\mathrm{t}+\mathrm{dt}}$ is moisture content at time $\mathrm{t}+\mathrm{dt}(\mathrm{kg}$ water/ $\mathrm{kg}$ dry mater), $\mathrm{M}_{\mathrm{t}}$ is moisture content at time $\mathrm{t}(\mathrm{kg}$ water/ $\mathrm{kg}$ dry mater) and $\mathrm{dt}$ is drying time (min).

\subsection{Specific energy consumption:}

Specific energy consumption is amount of energy required for removing unit amount of water from samples during drying of samples. Specific energy consumption of eggplant samples dried in different conditions was calculated asfollows equation (Sharma and Prasad, 2006).

$$
E_{s}=\frac{E_{T}}{W_{R}}
$$

Es : specific energy consumption $(\mathrm{MJ} / \mathrm{kg})$,

$\boldsymbol{E T}:$ total energy $(\mathrm{MJ})$,

$\boldsymbol{W R}$ : amount of water removed during drying $(\mathrm{kg})$. 


\subsection{Mathematical modeling of drying kinetics:}

Moisture ratio (MR) of during drying experiments was calculated using the following equation Togrul, and Pehlivan, (2003).

$$
M R=\frac{M-M_{e}}{M_{o}-M_{e}}
$$

where $\mathrm{M}$, Mo, and Me are moisture content at any drying time, initial moisture content and equilibrium moisture content ( $\mathrm{kg}$ water $/ \mathrm{kg}$ dry matter), respectively.

The drying curves were fitted with different moisture ratio equations given by several researchers, as listed in Table (1).

Table (1): Mathematical models applied to the drying curves.

\begin{tabular}{|c|c|c|c|}
\hline No. & Model name & Model expression & References \\
\hline 1 & Newton & $M R=\exp (-k . t)$ & Mohamed et al. (2005) \\
\hline 2 & Page & $M R=\exp \left(-k \cdot t^{n}\right)$ & Page (1949) \\
\hline 3 & Henderson and Pabis & $M R=\operatorname{a.exp}(-k . t)$ & Henderson and Pabis (1961) \\
\hline 4 & Logarithmic & $M R=a . \exp (-k . t)+c$ & Yagcioglu et al. (1999) \\
\hline 5 & Two term & $M R=a \cdot \exp \left(-k_{0} \cdot t\right)+b \exp \left(-k_{1} \cdot t\right)$ & Mohamed et al. (2005) \\
\hline 6 & Two term exponentials & $M R=a . \exp (-k . t)+(1-a) \exp (-k . a . t)$ & Yaldiz and Ertekin (2001) \\
\hline 7 & Wang and Singh & $M R=1+a \cdot t+b t^{2}$ & Wang and Singh (1978) \\
\hline 8 & Approximation of diffusion & $M R=a \exp (-k . t)+(1-a) \exp (-k . b . t)$ & Yaldiz and Ertekin (2001) \\
\hline 9 & Modified Henderson and Pabis & $M R=a \exp (-k . t)+b \cdot \exp (-g . t)+c \cdot \exp (-h . t)$ & Henderson (1974) \\
\hline 10 & Verma et al. & $M R=a \exp (-k . t)+(1-a) \exp (-$ g.t $)$ & Verma et al. (1985) \\
\hline 11 & Midilli-Kucuk & $M R=a \exp \left(-k . t^{n}\right)+b . t$ & Midilli et al. (2002) \\
\hline
\end{tabular}

The values of the coefficient of determination $\left(\mathrm{R}^{2}\right)$, chi-square $\left(\chi^{r}\right)$ mean bias error (MBE) and root mean square error (RMSE) are used to determine the quality of the drying model. The highest $\mathrm{R}^{2}$ values and lowest the values of MBE and the RMSE are selected to estimate the drying curve is the best (Ibrahim et al.2009) and (Sorour and El-Mesery 2014).

$$
\begin{aligned}
& M B E=\frac{1}{N} \sum_{i=1}^{N}\left(M R_{\text {pre },}-M R_{\text {exp }, i}\right)^{2} \ldots \\
& R M S=\left[\frac{1}{N} \sum_{i=1}^{N}\left(M R_{\text {pre }}-M R_{\text {exp }, i}\right)^{2}\right]^{\frac{1}{2}} \ldots \\
& \chi^{2} \quad=\frac{\sum_{i=1}^{N}\left(M R_{\text {exp }, i}-M R_{\text {pre }, i}\right)^{2}}{N-n} \ldots \ldots \ldots \ldots \ldots \ldots \ldots \ldots
\end{aligned}
$$


Where:-

$$
\begin{aligned}
& \mathrm{MR}_{\text {exp }, \mathrm{i}}=\text { the experimental moisture ratio. } \\
& \mathrm{MR}_{\text {pre, }}=\text { the predicted moisture ratio. } \\
& \mathrm{N} \quad=\text { the number of observations } \\
& \mathrm{n} \quad \text { = number of constants. }
\end{aligned}
$$

\section{3- RESULTS AND DISCUSSION}

\subsection{Drying kinetics of eggplant samples:}

The initial moisture content of the eggplant slices was around $93 \%$ wet basis (13.28 g water/g dry matter). Figures 2, 4, 6, and the table (2) present the moisture contents of the eggplant slices after the drying process in the microwave oven and before burning directly for different powers and thicknesses of the eggplant slices.

Table (2): Eggplant slices moisture content (\% w. b) after drying by the microwave with different powers and different times.

\begin{tabular}{|c|c|c|c|c|c|c|c|c|c|c|c|c|}
\hline $\begin{array}{c}\text { Microwave } \\
\text { power } \\
\text { [Watt] }\end{array}$ & \multicolumn{9}{|c|}{450} & \multicolumn{7}{c|}{} \\
\hline $\begin{array}{c}\text { Slices } \\
\text { thickness } \\
\text { [mm] }\end{array}$ & 5 & 10 & 15 & 20 & 5 & 10 & 15 & 20 & 5 & 10 & 15 & 20 \\
\hline $\begin{array}{c}\text { Drying } \\
\text { time [min] }\end{array}$ & 13.6 & 20.66 & 26.83 & 32.33 & 10.5 & 12.66 & 15.66 & 19.83 & 8.5 & 10.66 & 13.66 & 14.83 \\
\hline $\begin{array}{c}\text { Final } \\
\text { moisture } \\
\text { content } \\
{[\%]}\end{array}$ & 2.29 & 2.17 & 1.56 & 1.25 & 0.036 & 0.038 & 0.051 & 0.016 & 0.039 & 0.029 & 0.023 & 0.021 \\
\hline
\end{tabular}

Figures, 3 (a, b, c, and d), 5 (a, b, c, and d), and 7 (a, b, c, and d) present the effects of different microwave powers and the eggplant different thicknesses on moisture content at the final minute of different drying time before burning directly at the different powers and the different thicknesses of eggplant slices.

The previous results clarify that, the moisture content of the eggplant slices was very high during the initial phase of the drying, which resulted in a higher absorption and higher drying rates due to the higher moisture diffusion for higher microwave oven power and lower slices thickness. As the drying progressed, the loss of moisture in the product caused a decrease in the absorption of microwave oven power and resulted in a fall in the drying rate. 


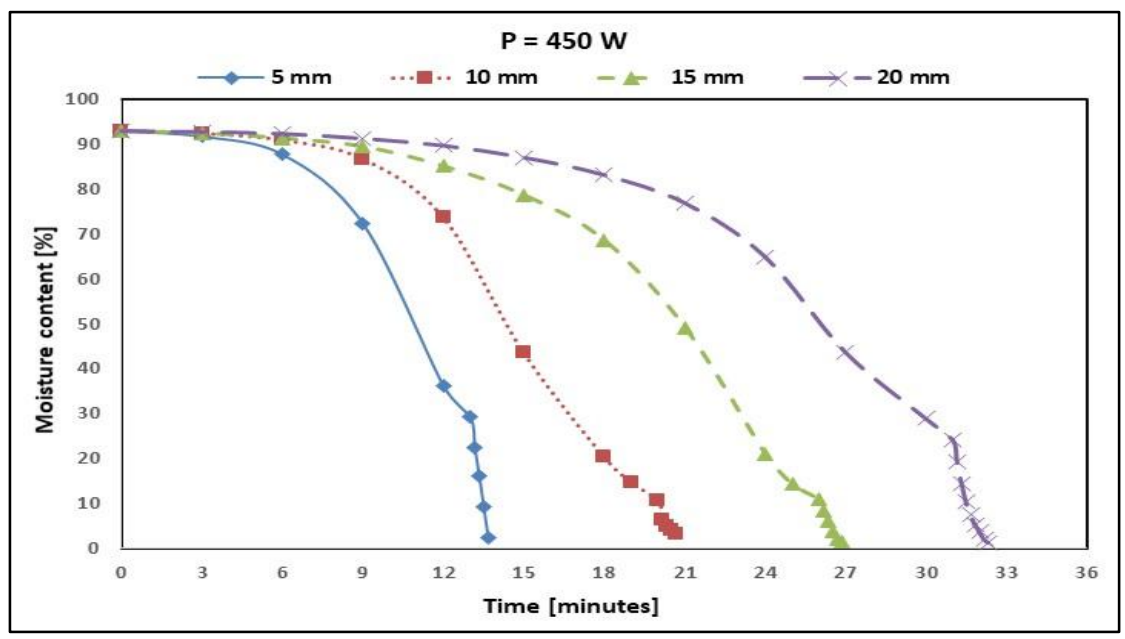

Fig. (2): The effect of drying time (min) on the moisture content (\% wb) of eggplant slices for different thickness at microwave oven power of 450 Watt.

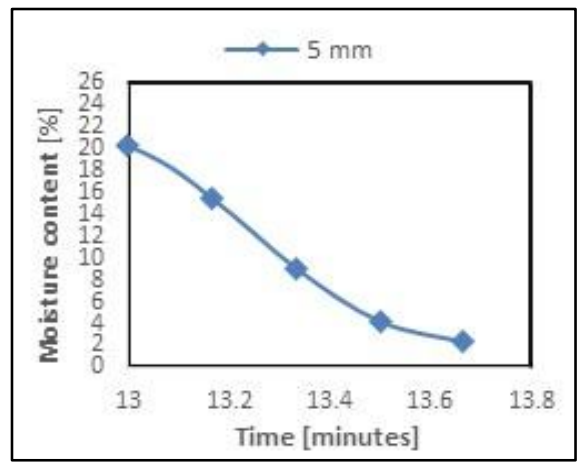

(a): $5 \mathrm{~mm}$

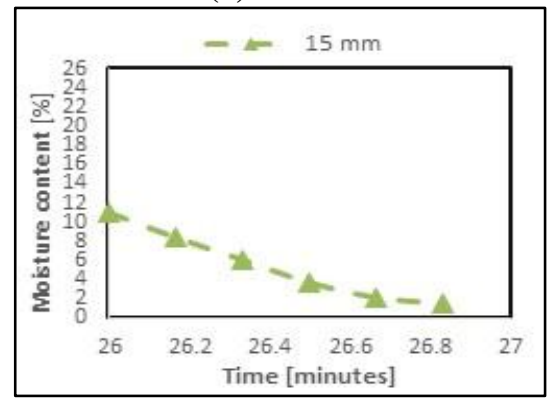

(c): $15 \mathrm{~mm}$

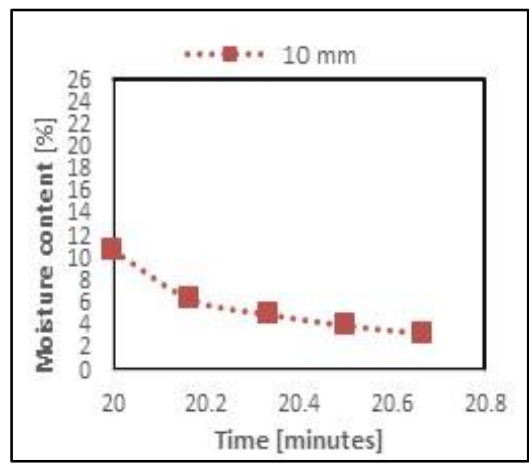

(b): $10 \mathrm{~mm}$

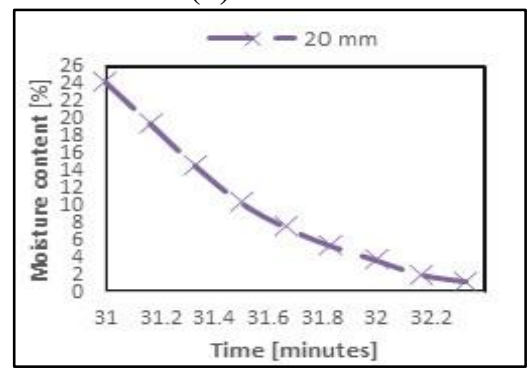

(d): $20 \mathrm{~mm}$

Fig. (3): The effect of drying time (min) on the moisture content (\% wb) of eggplant slices for at microwave oven power of 450 Watt for the burning point of $5,10,15,20 \mathrm{~mm}$ slice thickness. 


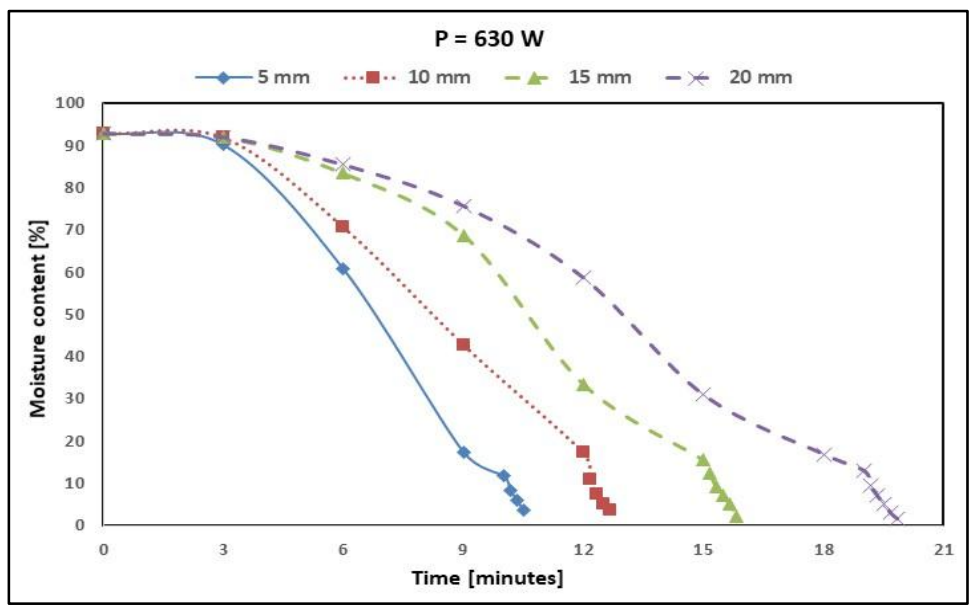

Fig. (4): The effect of drying time (min) on the moisture content $(\% \mathrm{wb})$ of eggplant slices for different thickness at microwave oven power 630 Watt.

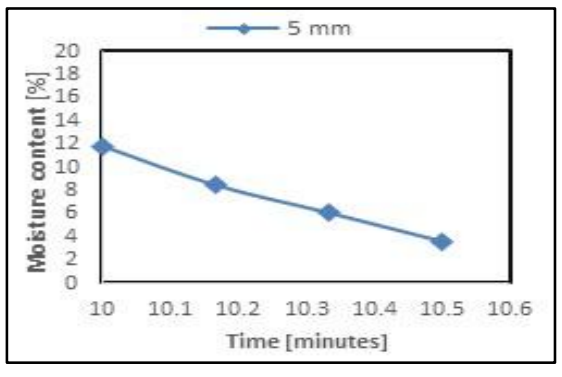

(a): 5 mm

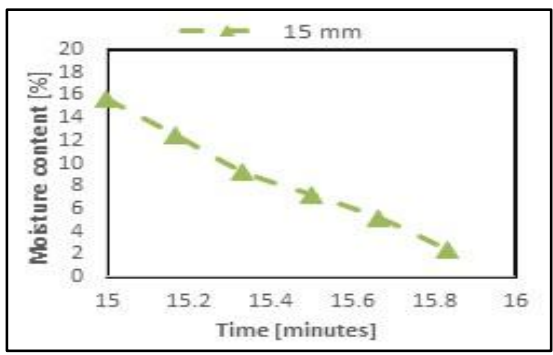

(c): $15 \mathrm{~mm}$

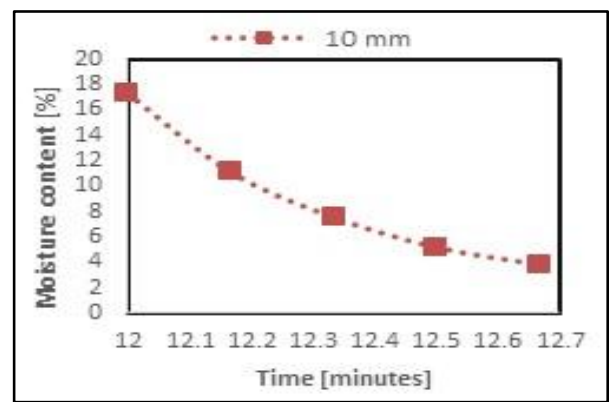

(b): $10 \mathrm{~mm}$

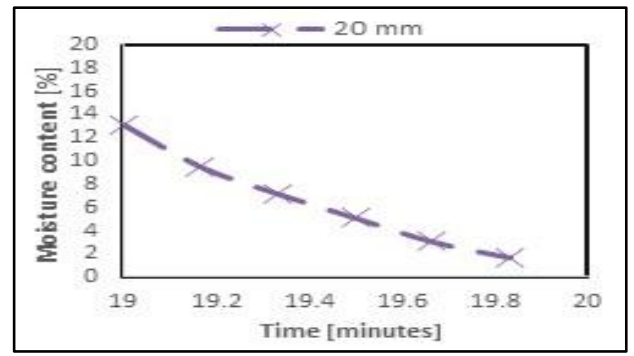

(d): $20 \mathrm{~mm}$

Fig. (5): The effect of drying time ( $\mathrm{min}$ ) on the moisture content (\% wb) of eggplant slices for different thickness at microwave oven power of 630 Watt for the burning point of 5, 10, 15, $20 \mathrm{~mm}$ slice thickness. 


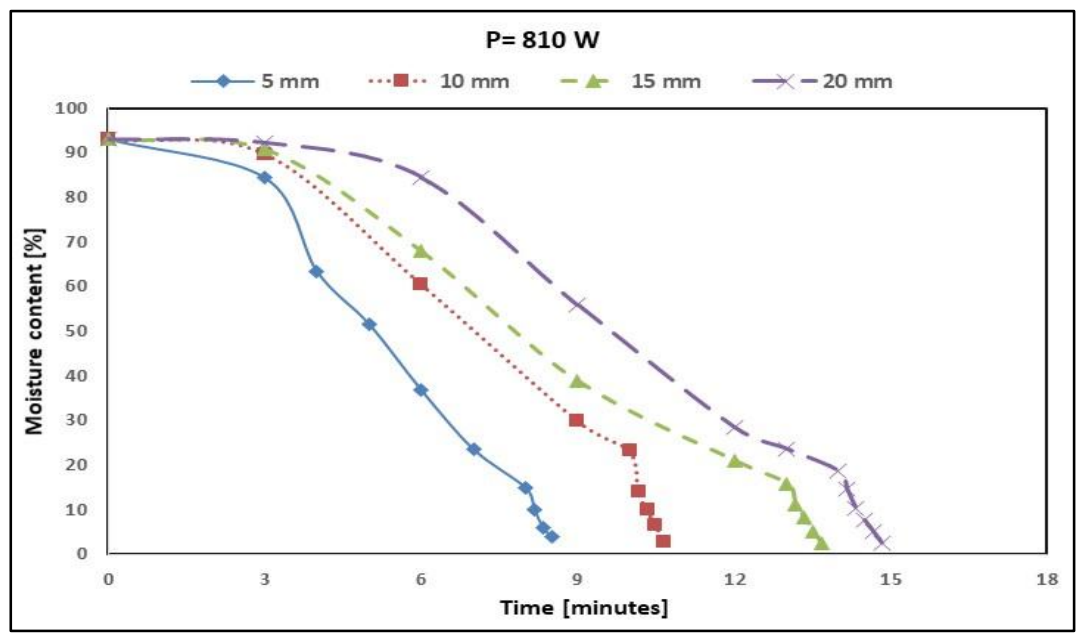

Fig. (6): The effect of drying time (min) on the moisture content (\% wb) of eggplant slices for different thickness at microwave oven power of 810 Watt.

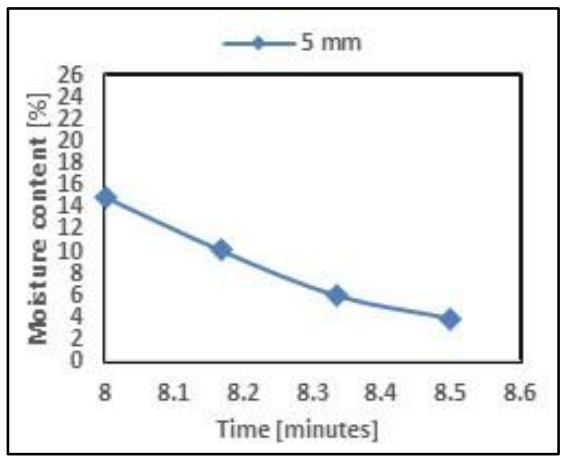

(a): $5 \mathrm{~mm}$

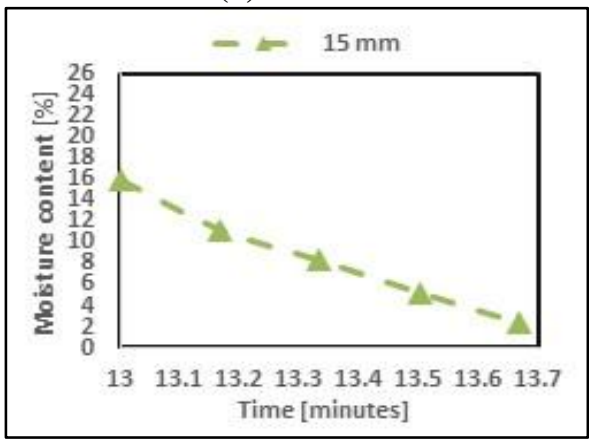

(c): $15 \mathrm{~mm}$

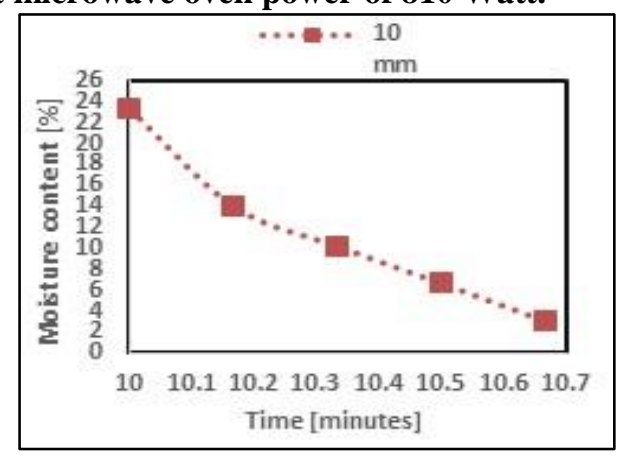

(b): $10 \mathrm{~mm}$

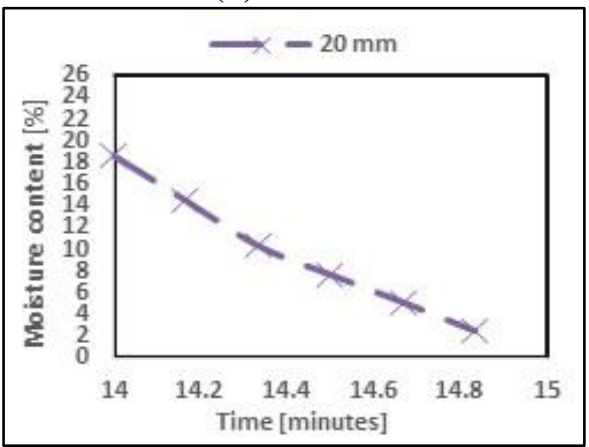

(d): $20 \mathrm{~mm}$

Fig. (7): The effect of drying time (min) on the moisture content (\% wb) of eggplant slices for different thickness at microwave oven power of 810 Watt for the burning point of $5,10,15,20 \mathrm{~mm}$ slice thickness. 
The previous results clarify that, the moisture content of the eggplant slices was very high during the initial phase of the drying, which resulted in a higher absorption and higher drying rates due to the higher moisture diffusion for higher microwave oven power and lower slices thickness. As the drying progressed, the loss of moisture in the product caused a decrease in the absorption of microwave oven power and resulted in a fall in the drying rate. The mass transfer within the sample was more rapidly during higher microwave power heating ( $810 \mathrm{watt})$ and lower thickness $(5 \mathrm{~mm})$ of the eggplant slices because more heating was generated within the sample creating a large vapor pressure difference between the surface and the center of the eggplant slices due to characteristic microwave oven. These results were the similar results reported by (Khodabakhshi, et al. (2015). Nonlinear regression analysis using Datafit program Version 9.1 (2014) was applied on the data of eggplant slices drying using Microwave oven, the relationship between effect of eggplant slices thickness (Th) by millimeter and drying time by minute (t) on change of moisture content (\%) shown in figures 8, 9, 10 at Microwave oven powers 450, 630 and 810 Watt respectively.

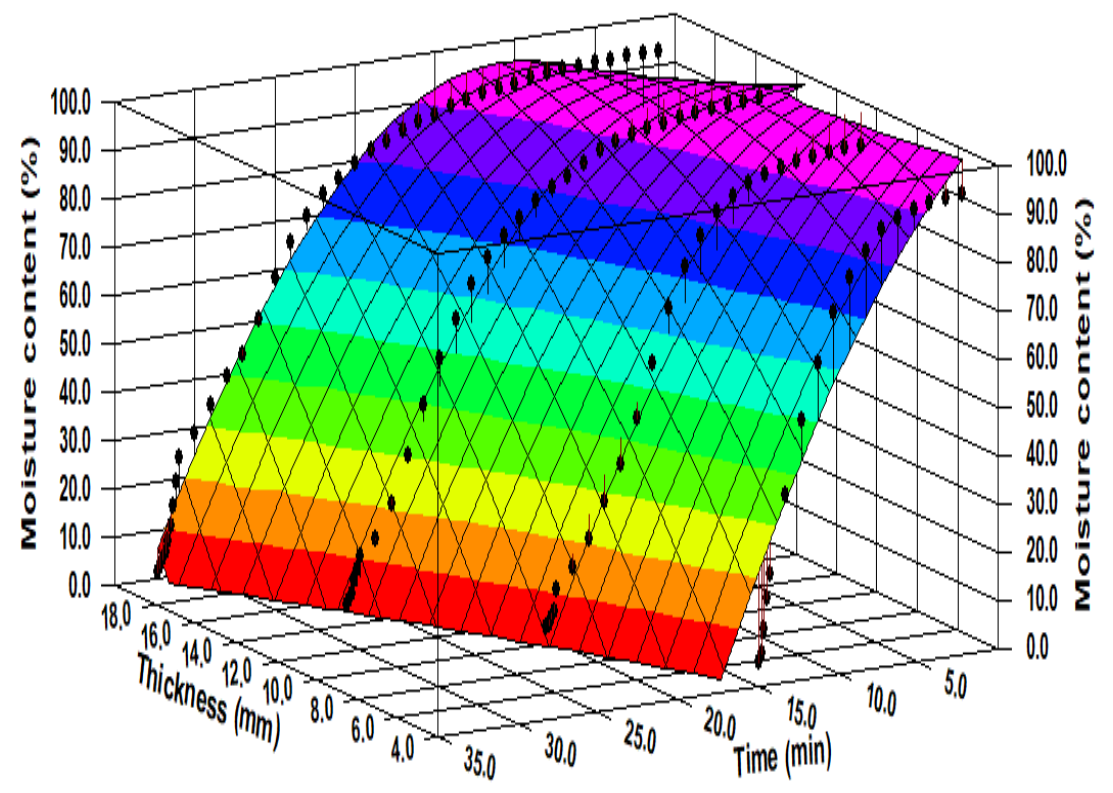

Fig. (8) The effect of eggplant slices thickness (Th) and drying time (t) on change of moisture content (\%) using Power 450 Watt. 


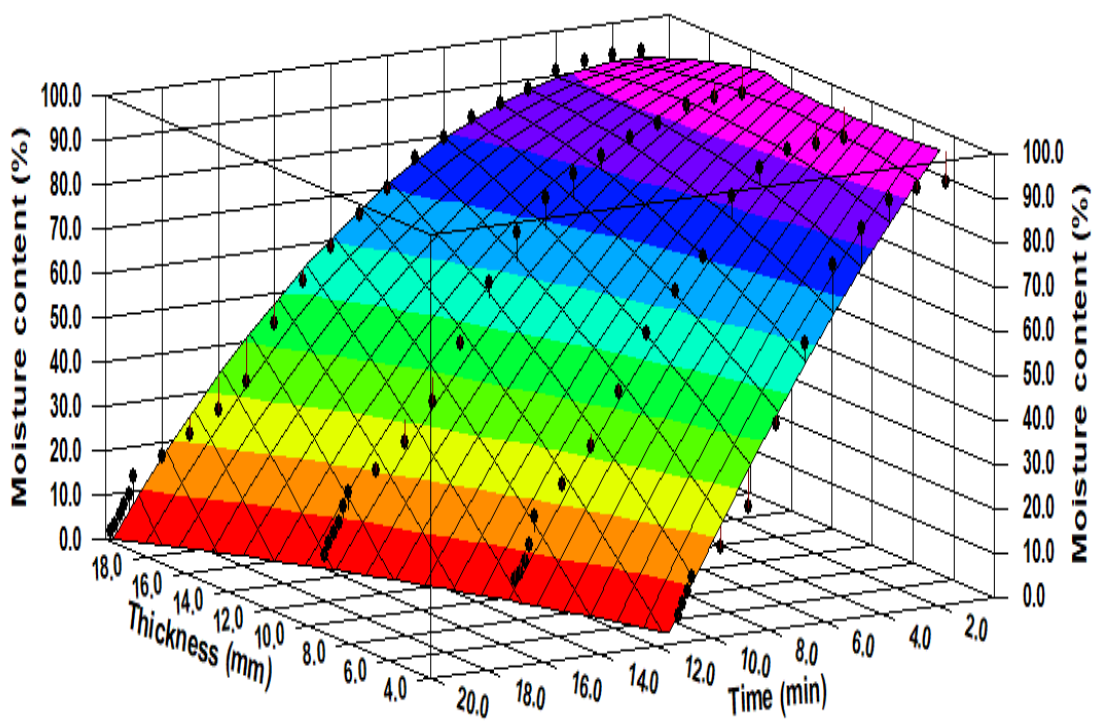

Fig. (9) The effect of eggplant slices thickness (Th) and drying time (t) on change of moisture content (\%) using Power 630 Watt.

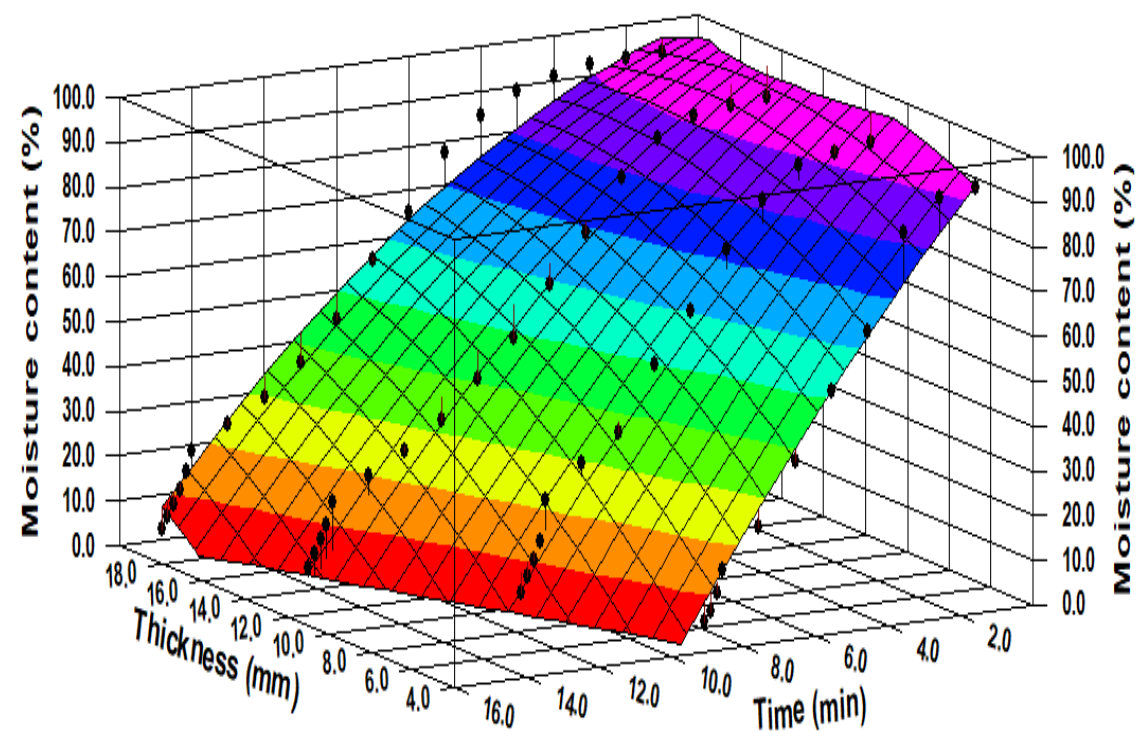

Fig. (10) The effect of eggplant slices thickness (Th) and drying time (t) on change of moisture content (\%) using Power 810 Watt.

The data of eggplant slices drying using microwave oven of our experimental can be described in equation (12):

$M_{o}(\%)=a+b \times(T h)+c \times(t)+d \times(T h)^{2}+e \times(t)^{2}+f \times(T h) \times(t) \ldots(12)$ The constants of this equation can be presented in the following table (3). 
Table (3) Equation Constants

\begin{tabular}{|c|c|c|c|}
\hline \multirow{2}{*}{ Constants } & \multicolumn{3}{|c|}{ Microwave power watt } \\
\cline { 2 - 4 } & $\mathbf{4 5 0}$ & $\mathbf{6 3 0}$ & $\mathbf{8 1 0}$ \\
\hline A & $\mathbf{9 2 . 6 4 7 5 3}$ & $\mathbf{1 0 6 . 9 4 8}$ & $\mathbf{8 8 . 1 1 4 9 4}$ \\
\hline B & $\mathbf{3 . 1 9 8 3 9 3}$ & $\mathbf{0 . 8 8 1 8 4 2}$ & $\mathbf{3 . 4 5 2 7 6 7}$ \\
\hline C & $\mathbf{- 5 . 8 8 0 1}$ & $\mathbf{- 9 . 8 6 1 4}$ & $\mathbf{- 1 0 . 9 1 3 6}$ \\
\hline D & $\mathbf{- 0 . 2 0 7 0 1}$ & $\mathbf{- 0 . 0 8 4 1 9}$ & $\mathbf{- 0 . 1 4 5 5 3}$ \\
\hline E & $\mathbf{- 0 . 1 9 1 8 1}$ & $\mathbf{- 0 . 2 6 5 8 2}$ & $\mathbf{- 0 . 2 5 5 8 7}$ \\
\hline F & $\mathbf{0 . 4 9 9 6 2 8}$ & $\mathbf{0 . 5 2 5 7 5 9}$ & $\mathbf{0 . 4 2 6 8 5}$ \\
\hline$R^{2}$ & $\mathbf{9 6 . 5}$ & $\mathbf{9 8 . 5}$ & $\mathbf{9 7 . 7}$ \\
\hline
\end{tabular}

\subsection{Drying efficiency of dried eggplants samples:}

From figure (11), it can be concluded that, the drying efficiency increases by increasing slices thickness at power levels 450, 630 and 810 Watt. The figure shows higher efficiency values when using 630 and 450 Watt respectively, and lower values when using 810 Watt except for $20 \mathrm{~mm}$ thickness, the efficiency was higher at 810 than 450 Watt. This is probably due to at $20 \mathrm{~mm}$ and the use of low power the drying rate is lower, while at 810-Watt power decreased due to surface intransigence.

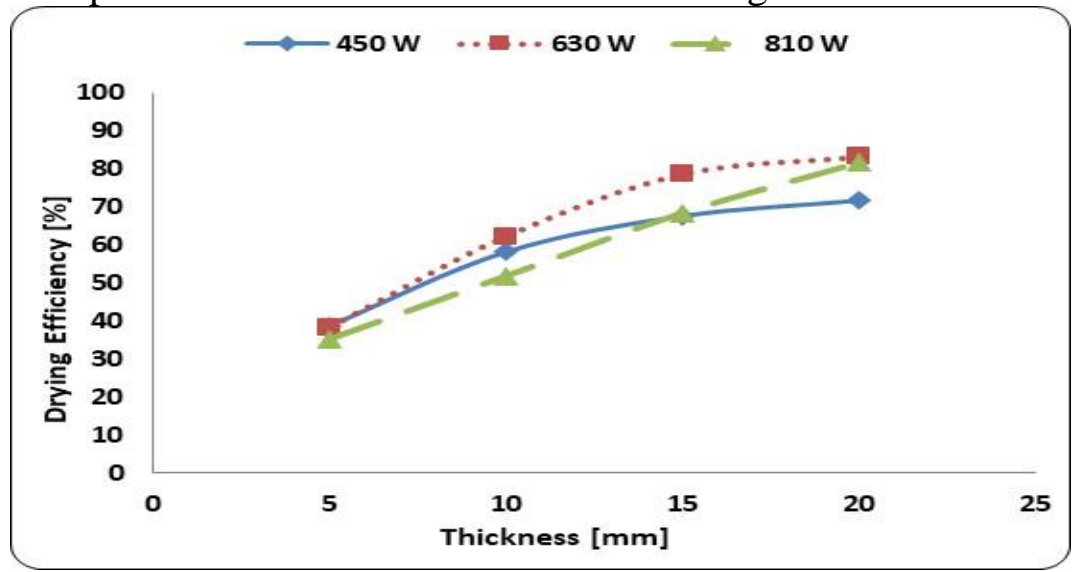

Fig. (11): The effect of eggplant slices thickness on drying efficiency using the microwave oven at selected power levels.

\subsection{Specific energy consumption:}

Figure (12) mentioned that the energy consumed per kg decrease with thickness increase, because the thickness increasing lead to increase the weight of eggplant on the unit area thus, the amount of energy is attributed to a larger weight, which leads to decrease. Also, we can show that when use thickness $5 \mathrm{~mm}$ due to surface intransigence at higher powers, 630 and 810 Watt, while at thicknesses 10,15 , and $20 \mathrm{~mm}$ an increase in energy 
consumption occurs at power 450 Watt this is due to the increase in drying time as a result to power decrease. The second higher energy consumption occurs at power 810-Watt surface intransigence which leads to an increase in drying time at this power, the increase in this time with that power leads to higher energy. The lower values of energy consumption occurred at power 630 Watt when thicknesses 10,15 , and $20 \mathrm{~mm}$ respectively.

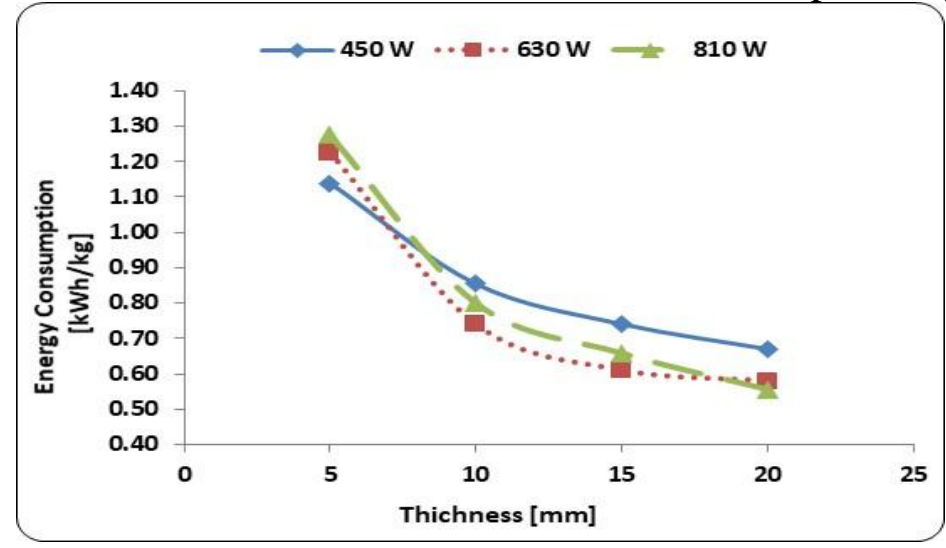

Fig. (12): The effect of eggplant slices thickness on the amount of energy consumed per $\mathrm{kg}$ by microwave oven at selected powers.

\subsection{Mathematical modeling of drying kinetics:}

The highest $R^{2}$ values and the values of MBE and the lowest RMSE values the fitting model was Page model which describe the drying curves of eggplant slices in Microwave oven, the following table (4) was present the constants of Page model for different treatment in this study.

Table (4): Constant page model and evaluation parameters

\begin{tabular}{|c|c|c|c|c|c|c|c|}
\hline \multicolumn{2}{|c|}{ Study treatments } & \multicolumn{2}{|c|}{ Constants } & \multicolumn{4}{|c|}{ Model evaluation } \\
\hline Power (Watt) & Thickness (mm) & $\mathbf{K}$ & $\mathbf{n}$ & $\mathbf{R}^{2}$ & MBE & RMSE & $\chi^{2}$ \\
\hline \multirow[b]{4}{*}{450} & 20 & $1.51 \mathrm{E}-03$ & 2.26 & 99.86 & 0.000181 & 0.013451 & 0.000185686 \\
\hline & 15 & $5.29 \mathrm{E}-03$ & 2.03 & 99.88 & 0.000148 & 0.012183 & 0.00015337 \\
\hline & 10 & $3.40 \mathrm{E}-03$ & 2.46 & 99.86 & 0.0002 & 0.014139 & 0.000208592 \\
\hline & 5 & $1.24 \mathrm{E}-02$ & 2.22 & 99.79 & 0.000296 & 0.017204 & 0.000314477 \\
\hline \multirow[b]{4}{*}{630} & 20 & 2.73E-02 & 1.81 & 99.38 & 0.000783 & 0.027985 & 0.000817182 \\
\hline & 15 & 2.68E-02 & 1.95 & 99.25 & 0.001023 & 0.031981 & 0.001076633 \\
\hline & 10 & 1.17E-02 & 2.71 & 99.35 & 0.000988 & 0.031431 & 0.0010538 \\
\hline & 5 & 2.99E-02 & 2.38 & 99.84 & 0.000243 & 0.015594 & 0.000263432 \\
\hline \multirow[b]{4}{*}{810} & 20 & 7.12E-03 & 2.68 & 99.84 & 0.000785 & 0.028025 & 0.000253936 \\
\hline & 15 & 2.58E-02 & 2.35 & 99.67 & 0.000556 & 0.023575 & 0.000477676 \\
\hline & 10 & 5.38E-02 & 2.05 & 99.59 & 0.00045 & 0.021203 & 0.000598556 \\
\hline & 5 & 6.14E-02 & 2.43 & 99.46 & 0.000241 & 0.01551 & 0.000863948 \\
\hline
\end{tabular}




\section{4- SUMMARY AND CONCLUSION}

The eggplants samples drying was done using microwave oven at three different levels of the maximum oven output of 900 Watt and $2450 \mathrm{MHz}$, which were 450, 630, and 810 Watt $(50 \%, 70 \%$, and $90 \%$ of 900 Watt). The results show that, the initial moisture content of the eggplant slices was around $93 \%$ wet basis (13.28 g water/g dry matter). The found results clarify that, the moisture content of the eggplant slices was very high during the initial phase of the drying, which resulted in a higher absorption and higher drying rates due to higher moisture diffusion for higher microwave oven power and lower slices thickness. The higher drying time occurred at used microwave $450 \mathrm{Watt}$ for drying eggplant slices $20 \mathrm{~mm}$ thickness, and the lower drying time occurred at used microwave 810 Watt for drying eggplant slices $5 \mathrm{~mm}$ thickness. the higher drying efficiency was $83.13 \%$ occurred when drying the eggplant slices $20 \mathrm{~mm}$ thickness in microwave oven at power 630 Watt. the higher total energy consumption per dry kilogram was 1.275 (KWh/ dry kg) occurred at used microwave 810 Watt for drying eggplant slices $5 \mathrm{~mm}$ thickness, and the lower total energy consumption per dry kilogram was $0.55(\mathrm{KWh} /$ dry $\mathrm{kg}$ ) occurred at used microwave $810 \mathrm{Watt}$ for drying eggplant slices $20 \mathrm{~mm}$ thickness.

\section{5- REFERENCE}

Akpinar, E.K. and Bicer, Y. (2005) Modeling of the drying of eggplants in thin-layers. International Journal of Food Science and Technology, 40, 273-281.

AOAC, (1980). Official methods of analysis (13th Ed.). Association of official analytical chemists, Washington, D.C.

Arikan, M. F., Arikan, Z., Soysal, Y., \& Esturk, O. (2012) Drying characteristics and quality parameters of microwave-dried grated carrots. Food and Bioprocess Technology, 5, 3217-3229.

Arslan D., and Ozcan M.M. (2011) Dehydration of red bell pepper (Capsicum annuиm L.): Change in drying behavior, colour and antioxidant content. Food and Bioproducts Processing, 89: 504-513.

Aydogdu, A. (2014) Microwave-infrared combination drying of eggplants. Master of Science in Food Engineering Department, Middle East Technical University. Turkey. 
Berk, Z. (2009) Dehydration. In Z. Berk, Food Process Engineering and Technology (pp. 459-510). Amsterdam: Academic Press.

Botha G.E., Oliveira J.C., Ahrne L. (2012) Quality optimization of combined osmotic dehydration and microwave assisted air-drying of pineapple using constant power emission. Food and Bioproducts Processing, 90: 171-179.

Chong, C. H., Figiel, A., Law, C. L., and Wojdyło, A. (2014) Combined drying of apple cubes by using of heat pump, vacuum-microwave, and intermittent techniques. Food and Bioprocess Technology, 7, 975-989.

Doymaz, İ. (2011) Drying of eggplant slices in thin layers at different air temperatures. Journal of Food Processing and Preservation, 35:280289.

Ertekin, C., and Yaldiz, O. (2004) Drying of eggplant and selection of a suitable thin layer-drying model. Journal of Food Engineering, 63, 349-359.

FAO. (2015) Production/Crops for Eggplant in 2013. Food and Agriculture Organization of the United Nations, Statistics Division.

Giri, S. K., P.P. Sutar and Suresh Prasad (2014) Effect of process variables on energy efficiency in microwave-vacuum drying of button mushroom. Journal of Food Research and Technology 2 (1): 31-38.

Harish A, Vivek B S, Sushma R, Monisha J, and Krishna Murthy T P, (2014) Effect of Microwave Power and Sample Thickness on Microwave Drying Kinetics Elephant Foot Yam (Amorphophallus Paeoniifolius) American Journal of Food Science and Technology, Vol. 2, No. 1, 28-35.

Henderson S M (1974) Progress in developing the thin-layer drying equation. Transactions of the ASAE, 17, 1167-1168/ 1172.

Henderson S M; Pabis S (1961) Grain drying theory I: temperature effect on drying coefficient. Journal of Agricultural Research Engineering, $6,169-174$.

Ibrahim, M., K. Sopian and W.R.W. Daud., (2009) Study of the drying kinetics of lemon grass. American Journal of Applied Sciences 6 (6):1070-1075. 
Jangam, S. V. (2011) An overview of recent developments and some r\&d challenges related to drying of foods. Drying Technology, 29: 13431357.

Khodabakhshi, A., Mandana, M., and Zarein, M., (2015) Investigation of Microwave Power Effects on Drying Kinetics and Energy Efficiency of Banana Samples. Global Journal of Science Frontier Research: D Agriculture and Veterinary Volume 15 Issue 4 Version 1.0 .

Margaris, D. P., and Ghiaus, A.G. (2008) Fruits and vegetables dehydration in tray dryers. In A. Urwaye, New Food Engineering Research Trends (pp. 45-101). New York: Nova Science Publishers Inc.

Midilli A; Kucuk H; Yapar Z (2002) A new model for single layer drying. Drying Technology, 20(7), 1503-1513.

Mohamed, L. A.; M. Kouhila; A. Jamali; S. Lahsasni; N. Kechaou; and M. Mahrouz (2005) Single layer solar drying behavior of Citrus aurantium leaves under forced convection. Energy Conversion and Management, 46:1473-1483.

Mohamed, M. A.; G. R. Gamea; and M. H. Keshek (2010) "Drying characteristics of okra by different solar dryers". Misr J. Ag. Eng. Vol. 27(1):294 - 312.

Murthy, T. P., and Manohar, B. (2012) Microwave drying of mango ginger (Curcuma amada Roxb): prediction of drying kinetics by mathematical modelling and artificial neural network. International Journal of Food Science and Technology, 47, 1229-1236.

Page, G (1949) Factors influencing the maximum rates of air-drying shelled corn in thin layers. MSc Thesis, Purdue University, Indiana, USA.

Puig A., Perez-Munuera I., Carcel J.A., Hernando I., and Garcia Perez J.V. (2012) Moisture loss kinetics and microstructural changes in eggplant (Solanum melongena L.) during conventional and ultrasonically assisted convective drying. Food and Bioproducts Processing, 90: 624-632.

Rakha, M.K.A (2014) growth, yield and fruit quality of eggplant (solanum melongena 1.) as affected by irrigation intervals and foliar application 
of some antitranspirants. J. Plant Production, Mansoura Univ., Vol. 5(12): 20692083.

Schiffmann, R. F. (2001) Microwave Processes for the Food Industry. In A. K. Datta, \& R. C. Anantheswaran (Eds.), Handbook of Microwave Technology for Food Applications (pp. 299-338). New York: Marcel Dekker.

Sharma G.P. and Prasad S. 2006. Specific energy consumption in microwave drying of garlic cloves. Enerji 31: 1921-1926.

Sorour, H.; AND EL-MESERY .H. (2014) Effect of microwave and infrared radiation on drying of onion slices. International Journal of Research in Applied, Natural and Social Sciences (IMPACT: IJRANSS) Vol. 2, Issue 5, May 2014, 119-130.

Sousa, W. A., Marsaioli Jr, A. and Rodrigues, M.I. (2004) Optimizing a microwave assisted banana-drying process. In: Silva, M.A. \& Rocha, S.C.S. (Eds.), Proceedings of the $14^{\text {th }}$ International Drying Symposium. São Paulo, Brazil, Vol. C, 1938-1945.

Soysal, Y., Oztekin, S., Eren, O., (2006) Microwave drying of parsley: modelling, kinetics, and energy aspects. Biosystems Engineering 93 (4), 403-413

Togrul, T. and Pehlivan, D. (2003) Modeling of drying kinetics of single apricot. Journal of Food Engineering, 58, 23-32. doi:10.1016/S02608774(02)003291.

Verma L R; Bucklin R A; Endan J B; Wratten F T (1985) Effects of drying air parameters on rice drying models. Transactions of the ASAE, 28, 296-301.

Wang C.Y; Singh R.P (1978) A single layer drying equation for rough rice. ASAE Paper No: 78-3001, ASAE, St. Joseph,MI.

Wu L., Orikasa T., Ogawa Y., and Tagawa A. (2007). Vacuum drying characteristics of eggplants. Journal of Food Engineering, Vol. 83, p. $422-429$.

Yaldız O; Ertekin C (2001) Thin layer solar drying of some different vegetables. Drying Technology, 19(3), 583-596.

Yongsawatdigul J; Gunasekaran S (1996) Microwave-vacuum drying of cranberries: -Part I: energy use and efficiency. Journal of Food Processing and Preservation, 20, 121-143. 


\section{الملخص العربحى}

\section{تجفيف شرائح الباذنجان باستخدام فرن الميكروويف}

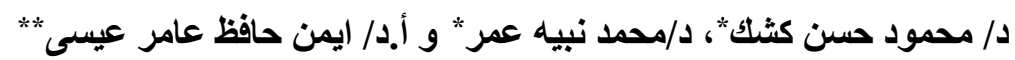

يعتبر الباذنجان أحد أهم المحاصيل في موسم الصيف ، ويزر ع الباذنجان في معظم مناطق مصر

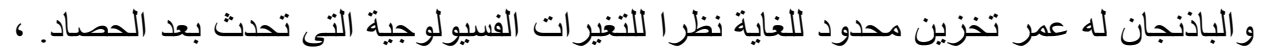

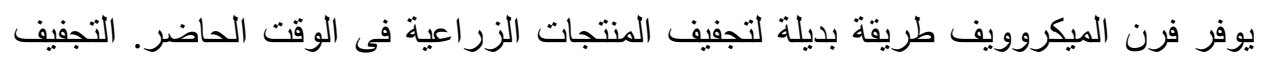
بالميكروويف ليس فقط أسرع ولكن أيضا يتطلب طاقة أقل من التجفيف التقليدي. الهدف الرئيسي من هذا البحث هو تقييم استخدام فرن الميكروويف في تجفيف الباذنجان ، لتحديد

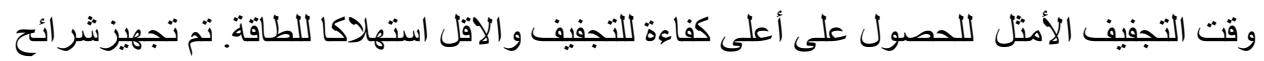

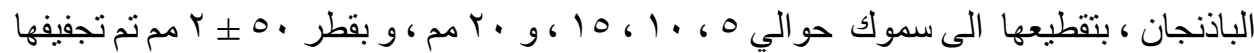

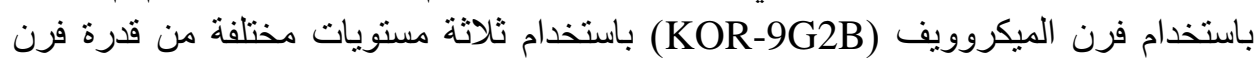

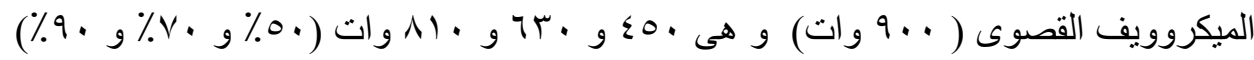
على الترتيب. أظهرت النتائج المحتوى ان الرطوبي الأبتدائي لثرائح الباذنجان كان سو٪

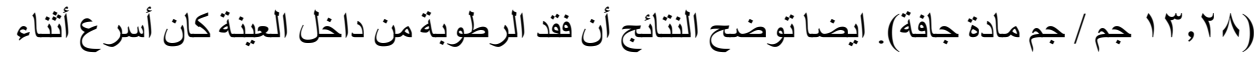

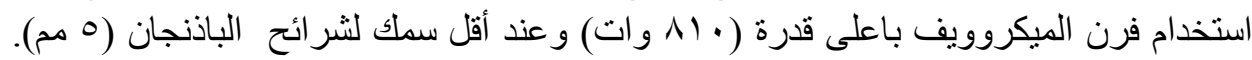

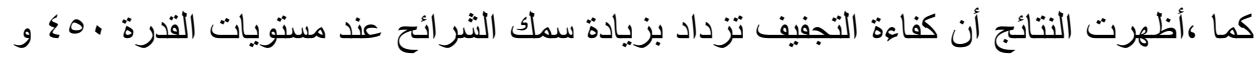

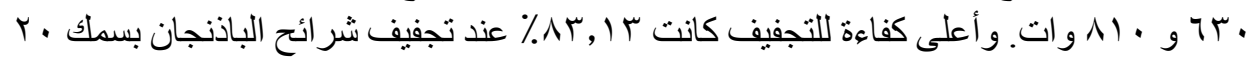

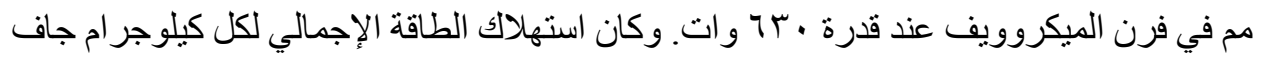

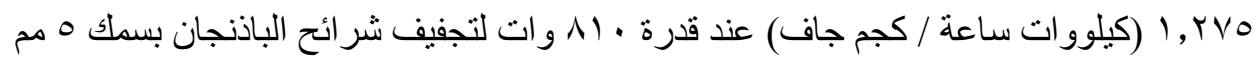

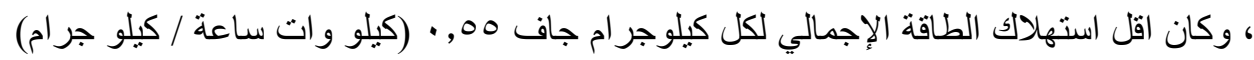

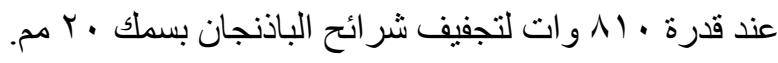

* مدرس الهندسة الزراعية قسم الهندسة الزراعية ـ كلية الزراعة ـ جامعة المنوفية.

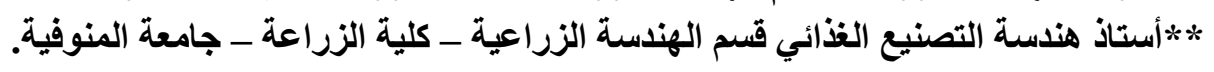

